\title{
Exploration of Micro-Finance Banking Policies and Strategies for Poverty Reduction in Nigeria
}

\author{
Umar Farouk Musa ${ }^{1}$ \\ Inuwa Baba Abubakar ${ }^{2}$
}

${ }^{1}$ Department of Political Science, Faculty of Social and Management Sciences,Bauchi State University, Gadau, Nigeria.

${ }^{2}$ Bauchi state Debt Management Agency, Gadau, Nigeria.

Correspondence: Umar Farouk Musa, Department of Political Science, Faculty of Social and Management Sciences, Bauchi State University, Gadau, Nigeria, Tel: +2348030910747, E-mail: umar_farouk@gsgs.uum.edu.my

Received: October 01, 2017

Accepted: October 05, 2017

Online Published: October 10, 2017

\begin{abstract}
Poverty is one of the socioeconomic challenges bed evilling many families, particularly the northern states of Nigeria. This study applied qualitative research paradigm and generated the perceptions of informants via convinience sampling. We analyzed the data through thematic, narrative and interactional apparoach. Our objective is to explore microfinance institutions strategic policies for poverty reduction and recommend to policy makers. The results exposed that micro financial institutions were classified into formal, informal, development and those with mortgage outlook.The Central Bank of Nigeria issue the certificate for authorization, the licensing and ownership. The Paid-up capital requirements, the permissible and acceptance of deposits, savings from individuals, groups and associations were the policies which propel these institutions. The non-permissible policies are restrictions on acceptance of public sector deposits. The study identified inadequate supervsions and loans defaults, poor infrasturectural facilities in rural areas, pitiable communication and derisory banking experience among the poor and low income earners, limited standardization and operating system as well hampered their services in the quest to mitigate poverty in the study area.The re-capitalization, efffective regulatory control via financial control, regularly supervision, checks and balances. Capacity building programs and Proper staffing.Provision of appropriate business model; strategies and creation of awareness. The provision of door to door banking marketing awareness, establishment of financial literacy; consumer protection programs and Provision of non-interest banking programs were perceived to overcome the perils of these institutions respectively. The study recommended for establishment of Islamic financial institutions and Takaful insurance scheme.
\end{abstract}

Keywords: Poverty Reduction, Microfinance Institutions, Types, Policies, Challenges, Strategies.

\section{Introduction}

The expansion of micro financial institutions started earlier in the form of informal cooperatives societies, micro credit and savings by various communities in Nigeria (Taiwo, Alege \& Olokoyo, 2016). However, the establishment of Grameen Bank in Bangladesh in the 1970s led to the adoption of modern formal financial 
institutions and banks in many developing countries. In the same vein, the government of Nigeria established various policies and programs to cover 65 percent of the economically active population by the year 2020 , improve the services of micro credit schemes, increase women access to financial services, jobs creation and poverty reduction.Nevertheless, literature indicated an unequal distribution of microfinance banks in the country. The northern part accomodates only 25 percent while the southern part of 75 percent respectively.These imbalances contributed to shortages of capital and increased poverty level in northern Nigeria. Studies equally reveal that the northern regions have higher of poverty indices for instance thenortheast 73.3 percent, west 77.7 percent and central 67.5 percent. These uncover that the northern region have higher socio-economic defies compared to the southern region. Other challenges bed eviling the north include jobnessness, illiteracy and crimes leading to the under developmentof this part of the country (Acha, 2012; Khan \& Cheri, 2016). Prior studies reveals that insufficiency of capital, misppropriation of funds, frequent change of government policies, inadequate technical skills and high risk as well as lost of loans recovery difficulties were some of the factors militating against the actvities of microfinancial banks in Nigeria (Edwin,Taiwo, Yewande, \& Benson, 2016). Literature attested that Nigeria microfinance institutions are emerging with unique structures compared to other African countries particularly the formalization policy of 2005 and effective 2008 transform community banks to MFIs. For instance in Zambia microfinance policies were unspecified but the government realizes the imperatives of under-banked; un-banked financial services for poverty reduction and established some regulations in the year 2006 (Siwale \& Okoye, 2017). These problems motivated this study in order to explore the strategies to address these imbalances; disparity affecting the country and specifically the north. The study is structure into introduction, research questions, objectives, and research methodology and data analysis. Four interview protocols were developed as well as literature review on the concept of microfinance and poverty.A thematic analysis was applied in aswering the research questions. The results were discussed and corroborated by previous studies. The recommendations; conclusion and references were as encapsulated.

\subsection{Research Questions}

- What are thetypes and policies established for micro-finance institutions to reduce poverty?

- What are the strategies to improvethe servicesof micro-finance institutions to reduce poverty in Nigeria?

2. Research Objectives

- To identify the tyes and policies established onmicro-financal institutions to reduce poverty.

- To explore the strategies of improving the services micro-financial institutions to reduce poverty.

\section{Research Methodology}

This study applied the qualitative research design; exploratory approach and convinience as well as snowball sampling framework. The population of the study covers the northern states of Bauchi, Jigawa, Niger and Kano states. Literature indicated that Bauchi and Jigawa state have high rate of poverty; while Kano have high concentration of microfinance institutions in the northern Nigeria while Niger state have high agricultural potentials. The data was collected from lecturers, bankers, individual customers of micro financial institutions and the poor alike.The study also adopted semi-structured interview and generated relevant data, thereby achieving the stated research objectives. We employed this approach due its adaptability, flexibility and compliance to the changing nature of the phenomenon under study (Creswell, 1994; Tansey, 2007). A thematic, narrative analysis, via interactional approach was adopted (Riessman, 2005; Riessman, 1993).The interaction facilitated the exploration of micro financial institutional types, policies, challenges and strategies to revamp its 
social services to mitigate poverty.

\subsection{Interview Protocols}

- Could you mention the types of micro-finance institutions in Nigeria?

- What are the policies that propel micro-finance instituions to mitigate poverty in Nigeria?

- What are the challenges of Micro-finacial institutions in Nigeria?

- Explain the strategies to improve the policies and services of Micro-finance institutions to reduce poverty.

\section{Literature Review}

This section of the study reviewed previous literature on the poverty and microfinance instutitions. The concept of poverty is broad and generic. However, the World Bank (2011), defined it as the condition of the absence of basic needs to enable individuals to live comfortably. The manifestations comprises of denial of education, portal driking water, health services, sanitation, low of expression, inadequate protection and social security (Ijaiya, 2015; Musa et al, 2016). Studies have identified different manifestation of poverty which include absolute or severe, relative, multidimensional and dollar per day poverty (Lame \&Yusoff, 2015; Ige, 2014; Hettne, 2002; Obikeze, \& Mathias, 2000). Absolute poverty is the severity in the acute shortage of food, educational support, sanitation and medical facilities, portable drinking water, low income; information and access to financial services. On the other hand, relative poverty is the condition in people faces the inadequancy of income needed to maitain an acceptable average standard of living in a country they live. These differ from country to country for instance relative poverty implies the position of a particular household or an individual in relation to the standard of living in a country. Relativity is measured in three elements of income, disposable income and low level of household income (Foster, 1998).

\subsection{The Concept of Micro-Finance}

The term microfinance refers to a broad range of monetary services to middle, low-income businesses as well as household. These services usually include loans, savings, leasing, insurance and transfer of monies among others. Microfinance instititions provides microcredit services and loans facilities to small and medium scale entreprises to generate income and provide employment opportunities.Studies indicated that micro-finance institutions were categorized into formal and non- informal structures.

The proliferation of microfinance institutions in Nigeria became into being in the form of microcredit facilities. These development addresses the challenges of inadequate financial services to the small scale businesses and the poor alike. Government provided some policies, initiatives, particularly through the promulgation of the cooperative society's ordinance 1963.

Primarily, these societies were regualted, supervised and coordinated by the department of cooperatives in the federal ministry of agriculture.The government established Nigerian, Agricultural and Cooperative Bank (NACB) in the 1973 and provided loans to small, medium and large scale via states governments in the country. The federal government equally launched Agricltural, Credit Gurantee Scheme Fund (ACGSF) in the year 1978 and was mandated to minimise risk associated with agricultural lending policies by banks and other natural occurence beyond the control of the farmers. The Central Bank of Nigeria later mandated universal or commercial banks to establish some of their branches in specific and identified rural communities and this led to the launching of over seven hundred branches in Nigeria (Adeyemi, 2008). This program was as well suspended in 1989. As result of this development, particularly in 1986 to 1990 these banks were neither having does not branch in the rural areas or does the legal framework survives. The country witnessed a serious set back in the 
rural banking programs immediately after the liquidation of many regional banks in 1993 and 2003 respectively. The scenario affected the poor, hence bankings services became difficulty.

Studies in many developing countries of Bangladesh, India, Indonesia, Philipinnes and Thailand indicated that despite the apparent defy, confronting microfinancial institutions particularly, administrative difficulties, systemic risk, repayment slog and absence of standardized informantion; these banks had recorded success, for instance the Grameen Bank in Bangladesh provided loans to the poorest in the rural areas, its women focused initiatives, about 94 percent of the beneficiaries and customers are the female folk, borrowing and lending were operated devoid of colleteral or security and the bank supported borrowers to excel in businesses;became selfreliant there by cushioning their surferings (Bakhtiari, 2011).

Literature divulge that the since 1984, the Bank Rakyat in Indonesia provided deregulated policy services via autonomous microfinance system to rural and urban customers. The bank had a massive staff recruitment, retraining and incentives. This development transforms the bank from ailing public financial institution into profitable, liberated and self-reliant financial intermediary. For instance, the 3,700local branches served a sum of 29.8 million savings accounts with 3.1 million borrowers as at 2001. The packages reach the rural poor as well as other entrepreneurs; influences their decision making capabilities and family wellbeing respectively (Panjaitan-Drioadisuryo, \& Cloud, 1999).

Studies in India indicated that Society for Helping Awakening Rural Poor through Education (SHARE) which stated operation in 1992 had substantailly grown into a microfinancial institution in the country; disbursed over 13 million USD loans to borrowers, 1.3 million and provided technical in addition to financial services to bearly 61,000 women living in abject poverty particularly rural areas of Andhra Pradesh state. These policy strategies, according to the results, usher in improved living condition, they became self employed and 50 percent of the beneficiaries had already traversed the poverty line (Bakhtiari, 2011).However, despite the achievements recorded by microfinancial institutions on poverty reduction in many developing countries as mention above, poverty remains one among the socioeconomic predicaments in parts of the world. Literature further supposed that countries such as India and Nigeria recorded economy growth but multidimensional poverty indices exist side by side along with other forms of deprivation in which policy makers consistently aspire for robust solutions (Aku, 2017; Alkire, \& Seth, 2015; Imai, Arun \& Annim, 2010).

Based on the above arguments, studies indicated that microfinance institutions were utilized as effective strategies in poverty reduction in Bangladesh, India, Indonesia, Philipinnes and Thailand. However, studies in other developing countries, specifically Nigeria, uncover that some predicaments were identified and rendered these institutions weak in the quest to reduce the paucity of resources. For instance insufficient capital, diversion of the funds, frequent change of government policies, inadequate technical skills and high risk as well as lost of loans recoverydifficulties were some of the factors militating against the actvities of microfinancial banks in Nigeria(Edwin,Taiwo, Yewande, \& Benson, 2016).

Okpara, (2010) studied the impact of microfiance banks and poverty alleviation in Nigeria using secondary data obtained from the National Bureau of Statistics and analysis the results through factor analysis. Findings from the survey reveals that low profit, inadequate capital to set of business and high prices of commodities were some of the factors that causes poverty in the Nigeria context. The study further discovered two major phases in which microfinance influence poverty reduction: the take-off stage, which explains that poverty is increasing while as at the year 2001, the proliferation of more microfinancial institutions led to the decrease of poverty level, thus, microfinance facilitated the reduction of paucity of resources in the country. The study 
recommendated for the government to established more microfiance institutions in the country. However, the study was limited to secondary data hence; survey on the causes of poverty requires primary data via interview and a survey.

In a study on the challenges and prospects of microfinance banking institutions in Nigeria, Acha, (2012) discovered that inadequate infratsructures, poor legal and regulatory institutions, social misconception, paucity of qualified manpower among others were the challenges of microfinance banks in the country. The study equally unveil that despite the aforementioned chllenges the growing entrepreneurial awareness, high population of the poor and increasing interest of the policy makers in allevaiting poverty were as well discovery to influence the viability and flourishment ofthese institutions. The study suggested for the restablishment of the regulations and articulated commitment to push microfinance banking instutitions in Nigeria. This study is constraint by the shortfall of proper methodological techniques in the process of data collection and unable to esatablish limitations as well as direction for future studies.

Based on the literature reviewed, several gaps were identified which this study intends to fill and explore startegies to cushion the difficulties the poor encountered in accessing microfinancial packages in the Nigeria context. For intance Bank Rakyat in Indonesia had yielded remarkable improvement on poverty reduction via uniformity of packages. While the Center for Agriculture and Rural Development (CA RD) had afforded 34,000 poorest women with capital and in the long run became self-employed in Philippines. Additionally, a sum of 17.25 million USD was disbursed and these development translated into poverty reduction via microfinance institutions (Bakhtiari, 2011).Liman, Hashim, \& Arshad, (2017) attested that microfinance institutions in Nigeria lacks uniform lending policies, organizational strategies and heterogenous in terms of ownership. They further identify that insufficient capital, frail legal framework, financial products and expertise services constraints, cummulated into fragile services rendered to their respective customers.

\section{Data Analysis and Results}

The results were articulated according to types of microfinance in Nigeria, policies, challenges and strategies to improve microfinance institutional services to reduce poverty respectively.

\subsection{Types of Micro-Finance Institutions in Nigeria}

The informants narrated that the types of microfinancial banking instututions in Nigeria consist of formal, informal, development and mortgage. Others include Community Bank,

Public or government owned, private and foreign microfinance and thus:

Formal Microfinancial institutions were design by the cenral bank of Nigeria purposely to provide financial services to the active poor population who were excluded from government financial institutions.Their services comprises of issuence of microcredits facilities, acceptance of deposits, facilitation of credit transfer and offering leasing as medium term finance (informant1).

The informal microfinancial institutions consist of cooperative credit society, community savings and loan associations. Cooperative credit society serve as associations of individuals that pooled resources collectively on mutual basis for specific socio-economic purposes. The community savings and credit schemesareforms of financial institutions established by societies for mutual benefits of their members. They are mostly owned by communities, they offer loans within the duration of three to six months with less than five percent and not more than twenty percent interest rate. These banks usually established a policy of repayment daily, weekly and monthly respectively. They offers a minimum loans package of ten thousand naira. The schemes were informal in nature with low interest rate (Informant 1\&5). 
Informant two maintained that microfinance were categorised into those engaging develoment programs such mortgaging, community financing services such as issuence of loans and microcredit facilities to the poor and low class citizens. These institutions equally provided financial services to with low interest rate, mostly one percent in Nigeria.

There are basically three different types of microfinance institutions in Nigeria and specifically in Kano: Public owned microfinance banks with about thirty eight branches in the state such as Gaya, Dambatta-Makoda, Access, Albasu, North Bridge, Sauna and Municipal microfianance banks respectively.Commmunity microfinance banks especially in the southern part of Nigeria. There are equally those with Islamic packages and orientation. These are called Islamic microfinance banks (Informant four).

Informant five, attested that microfinancial banks in Nigeria are categorised into community, private, NGOs, public and foreign institutions. For instance the public owned MFIs offers a minimum loans facility of ten thousand for duration of six months and repayment installment period of weekly and monthly.The NGOs usually offers loans packages with a minimum amount of ten thousand naira for duration of six months and repaymen period of daily and weekly respectively.

These were the classifications and types of MFIs in Nigeria, based on the supposition of the informants. Literature indicated that the practice ofinformal microfinances arrangements existed in Nigeria in the form of self help organizations called rotating savings; credit union and cooperative societiesrespectively (Siwale \& Okoye, 2017).

\subsection{Policy Thrusts on MFIs as Poverty Reduction Strategies}

In recognition of the economic and social developmental roles of MFIs on poverty reduction, the Central Bank of Nigeria launched the National Microfinance Regulatory Policy, and Supervisory Framework (NMPRSF) in the year, 2000 and 2011 respectively.A comprehensive review on the policy for the development and expansion of microfinance institutions, the National Microfinance Development Strategy (NMDS) were to revamp the industry and overcome the challenges of the earlier policies.

Informant Four maintained that:

The aforementioned policies were established to ensure the MFIs become efficient and accessible to the poor both in terms of financial services as well as cover 65 percent of the economically active people by 2020. To increase the share of micro credit from 0.9 percent in 2005 to 20 percent in the year 2020, promotion of the participation of at least two-thirds of the states and local governments, reduction of gender disparity and improve women`s accessibility to financial services by 15 percent annually and increase synergy among MFIs and other financial institutions by 10 percent annually.

He further upheld that to achieve these objectives, the following policies were established. The licensing and ownership: The CBN provides the license to them to operate as Community Banks, Private MFIs, Government MFIs, NGO MFIs and Foreign MFIs. The CBN equally, determines the ownerships of these MFIs include individuals, group of individuals, government body, community development associations, private corporate entities and foreign investors respectively.

Paid-up capital requirements, include unit Microfinance Banks, the state MFIs and the national MFIs. For instance, the unit Microfinance Banks are authorized to operate in only one location and is required to have a minimum paid-up capital of N2O million (twenty million Naira). The state MFI is authorized to operate in only one State or the Federal Capital Territory (FCT), Abuja and is required to 
have a minimum paid-up capital of N100 million (one hundred million Naira). The national MFIs is required to have a minimum paid-up capital of $N 2$ billion (two billion Naira) and is authorized to operate in more than one state, including the FCT, Abuja respectively.

The permissible and acceptance of several types of deposits including savings, time, and target from individuals, groups and associations. The provision of credit to its customers the formal and informal self-help groups, individuals and associations.Promotion and monitoring of loan usage among its customers by providing ancillary capacity building in areas such as record keeping and small business management.Others include buying, selling and supplying industrial and agricultural inputs, livestock, machinery and industrial raw materials to low-income earners on credit and to act as agent for any association for the sale of such goods or livestock.

The non-permissible activities are prohibited from engaging in the following activities: Acceptance of public sector (government) deposits.Foreign exchange transactions.International commercial papers. International corporate finance; International electronic funds transfer; Clearing house activities and dealing on land or any facility for speculative purposes. Financing of any illegal/prohibited activities such as gambling, drug-trafficking, and firearms.

\subsection{Challenges of MFIs in the Nigeria}

The informants categorically identified different problems which hampered the services of MFIs in the quest to mitigate poverty in Nigeria and specifically the northern states; these includes; Lack of access to electricity supply; Inadequate supervision and loan defaults. Unsustainable intervention programs; Insufficient cheap funds; Low public awareness and poor regulatory enforcement; poor communication and deficiency of banking experiences among poor and low-incomeearners; High operating cost; Low literacy rate among the population; Insufficient donor funding, loan and equity.Limited standardized reporting and performance monitoring system.Lack of good roads and transportation system respectively. Kanu, 2017, pinpointed difficulties related to infrastructure, finance and other predicaments especially in rural areas.

For instance, informant four attested that:

Lack of access to regular electricity supply appeared to be the most common and pressing challengefaced by MFIs in Nigeria. This is probably due to the insufficiency of electricity supply in the country. The estimated electricity supply in the country is as low as 1,327 megawattsNevertheless, the average usage of electricity amounted to 10,000MW.

Literature, attested that out of the 23 electricity plants stations in the country, only five are functional(Udo, 2015). These implies thatMFIs have to source generate power via generators to provide the electricity they needed in running their administrative and business operations.

The study found that MFIs have inadequate supervision and seen to experiencing loans default. The lack of supervision as well as control in operational procedures which affected not only their loan disbursement and repayment but also in some cases resulted in fraudulent practices among the staff of the MFIs (Informant four).

The informants opined that intervention programs for MFIs provided by the government were unsustainable.Generally, they have limited source of funding and therefore, needed financial support to expand their lending packages.Most MFIs in Nigeria wereprimarilyreinforced by the government, large companies and non-government organizations. However, the amount and types of assistance provided to MFIs are limited on short basis. 
Insufficient funds: Another pressing problem faced by the MFIs as identified in the study involved the lack of access to cheap funds. Given this challenge they needed expansion of lending capabilities; MFIs were compelled to borrow additional funds from conventional banks. However, borrowing from the banks is sharply inconvenient for them. The commercial banks charge the MFIs an interest rate of 22 percent per annum on theseloans. (CBN, 2016).

Low public awareness and regulations: These problems affected their performance in poverty reduction process, certain proportion of the population in the country, especially at the rural areas are still not familiar with the types of financial products and services provided by the MFIs. Additionally, the introduction of lending regulations has also limited their abilities in loan services. These regulations restricted them from accepting cash deposit from their customers. The restrictionsaffected the liquidity of these financial institutions.

Lack of infrastructural facilities such as roads and transportation system has also affected the operations of the MFIs. The informants indicated that good roads are needed to link their institutions with customers in the urban and rural areas across the country.Literature divulge that about one third of the network of roads in Nigeria needs to be rebuilt (Akinwale, 2010).

\subsection{Strategies to Improve MFIs Services to Reduce Poverty in Nigeria}

The informants suggested for efffective regulatory control via financial control, regular supervisor and checks as well as balances to enhance their performance. Capacity building programs and Proper staffing were equally suggested.Provision of appropriate business model; strategies and creation of awareness. The provision of door to door banking marketing awareness, establishment of financial literacy; consumer protection programs and Provision of non-interest banking programs respectively.

For instance, in order to improve the services of the microfinance banks, there is the need for the expansion of access to capital to the poor and reduction of the interest rate or where necessary an interest free services. These will go along way in allevaiting poverty (Informant three).

Literature indicated that microfinancial institutions provided loans and other financial services to the low income and the poor. It further play significant roles in economic development, poverty reduction, employment generation and easy access of loans to small scale business in Kwara state, Nigeria (Yahaya \& Osemene, 2011).

Informant three: Recapitalisation and innovations: These institutions required more capital in order to increase accessibility of the funds by the small scale business and the poor. Other attractive revolutions such as marketing of the products and services in the villages will influence the entrepreneurs and farmers to patronised MFIs activities.

Literature attested that recapitalization of microfinancial banks will ensure vibrant support for small scale business and enhance proper management of loans disbursement as well as granting adequate credit facilities to poor and small scale businesses operators (Taiwo, Yewande, Edwin \& Benson, 2016).

Establishment of additional branches across towns and villages. The expansion of MFIs services to remote areas will accelerate easy access to their services and encourage competition across the towns and villages .I suggested for establishment of three to five branches in each LGA especially in the northern part of Nigeria( Informant Three).

I am of the view that MFIs needs focused to specific sectors of the economy for instance if individuals are interested in agriculture, the loans services should be perculiar to agriculture, small and medium scale enterprises, transportation and other services requires (informants Three). 


\subsection{Discussion}

This study utilized the thematic and interactional narrative data analysis method in which the results were discussed according to the research questions and facilitated the achievements of the stated objectives. Thus, theme one answered research question one and theme two answered the second question respectively.

Theme one, addressed the types and policies adopted by the government and other operators of microfinancial banking institutions to reduce poverty. The results reveals that the different formsand practices of microfinancial banking instututions in Nigeria include formal, informal, development and mortgage. Others comprise of community Banks, public or government owned, private and foreign microfinance institutions.

Literature divulge that the informal microfinancial institutions existed before the establishment of the formal banks in all parts of the countryand provided some traditional forms of banking services for the mutual benefits for their members such as savings and credits facilities to carry out their businesses. On the other hand the formalized institutions provided services in the areas of savings, credit and insurance. The formal institutions targeted the improvement of the socio-economic status of women particularly in the rural areasvia loans, skills aquisitions, adult literacy and reproductive health care. The services equally covers community services on wealth creation amid the poor and the entrepreneurs respectively (Olomola, 2002).Prior studies indicated that the inability of the formal financial bodies to provide efficient services to the rural and urban poor; the unsustainable attitude of the public financial institutions led to the proliferation of the private microfinancial banks in Nigeria. The foreign MFIs are those owned by some multinational corporations, shareholders and partners (Liman, Hashim \& Arshad, 2017; Anyanwu, 2004). The informants maintained that other forms of MFIs consist of those with mortgage and developmental outlook which finance housing and other long term businesses.

The central bank of Nigeria regulated and supervised the MFIs in the country. There were different policies which legalize their activities, in same vein the informants narrated that National Microfinance Development Strategy (NMDS) were established to revamp the industry and overcome the challenges of the earlier policies and the National Microfinance Regulatory Policy, and Supervisory Framework (NMPRSF) in the year 2000 and 2011 respectively.These policies comprises of the licensing and ownership. The Central Bank of Nigeria issue the certificate for authorization to all the categorize of MFIs such community, Private, Government, NGO and Foreign MFIs. The CBN likewise regulated the ownerships of these MFIs either individuals, or group of individuals, state or local government body, community development associations, private corporate entities and foreign investors respectively. These currently defines the size, duration of loans and initial capital to set up MFBs. Preceding study uphold that the regulations wereprofessionally organizedbut yielded insignificant impact on the empowerment of the poor in the country (Siwale \& Okoye, 2017).

The paid-up capital requirements policy which encompasses the operational permission on the aspect capital and coverage in the states, the federal capital and the country at large.For instance, a sum of twenty million pay-up capital are required for states MFIs whereas the FCT and the national branches should have one hundred million and two billion naira respectively. Literature indicated that viable capitalization requirement depends on the geograhical coverage of these banks, population, volume of business and scope.Thesefurther solidify their efficiencies as well as compentencies in making capital available for their customers (Ebomuche, Ihugba, \& Bankong, 2014).

Other regulatory policies consist of the permissibility and acceptability ofdifferent transactions such as savings, time, and targeted individuals, groups and associations. The MFIs provides credit to the customers formally and 
informal. They also promote and monitored loans disbursement particularly on capacity building in the areas of small business management and record keeping. Additionally, the policy permitted the buying, selling, and supply of industrial and agricultural inputs. The services also covers machinery and industrial raw materials to low-income persons on credit and to act as agent for any association for the sale of such goods or livestock. The MFIs were constrained from accepting public deposits, foreign exchange transtions, international corporate finance, commercial papers, electronic funds transfer and clearing house business. The policies equally restricted them from any facility for speculative purposes and financing illegal transtions such as gamling, firearms and drug-trafficking. Astudy from the Central Bank of Nigeria, attested that the rationale for the regulations were to ensure economic reforms and achieve price stability, employment, economic growth; internal and external balances as well as repostioned the country amid 20th vibrant economies by 2020(Sanusi, 2012).

Answering research question two, the informants identified and narrated various challenges bedevilling the successful operations of MFIs, especially in the study area which includes deficiency of access to electricity supply; inadequate supervision and loan defaults. Unsustainable intervention programs; insufficient cheap funds; low public awareness and poor regulatory enforcement; poor communication and low awareness in society; lack of banking experience among poor and low-income earners; high operating cost; low literacy rate among the population, insecurity in the northern eastern states; insufficient donor funding, loan and equity.Limited standardized reporting and performance monitoring system.Lack of good roads and transportation system in some rural areas respectively. Literature established and attested that there were cases of diversion of funds allocated for the loans packages to small scale farmers especially among public MFIs, other perils include inadequate finance to effectively operate, low capacity building and technical expertise in management of MFIs led to increase in the poverty level especially in the northern Nigeria (Taiwo, Yewande, Edwin \& Benson, 2016).

Re-capitalisation and innovations in addition to the establishment of additional branches across towns and villages.Prior study uphold that for MFIs to effectively function viable financial services should be establish and expand the coverage in addition to the scope of these institutions across rural areas. These services will go along way in influencing the small scale business to mitigate poverty especially in the northern part of the country (Ogujiuba, Jumare \& Stiegler, 2013).

The efffective regulatory control via financial control, regularly supervisor and checks as well as balances to ensure that these institutions operate within the premise of the guidelines, effective, efficient regulatory and supervisory fron the Central Bank of Nigeria and Nigerian Deposit Insurance Corporation.Futhermore, the roles of government in terms of establishing good governance practices, the poltical and economic environmental atmosphere shall boost MFIs especially via inclusive approach such as involvement other stakeholders in its administration(Ikeanyibe, 2009).Capacity building programs and Proper staffing were applied bythe stakeholders in equiping the client alongside skills acquisition, capabilities and empowerment services to benefit from the services offered by MFIs. These shall remedy some of the challenges of these organizations in poverty reduction. Again human resources management and development were proposed in strengthening the manpower needed in the overal achievement of inter and intra organizational productivity in the areas of staff selection, training, compensation and addressing the core areas of poverty alleviation, unemployment and inequality (Ikeanyibe, 2009).Provision of appropriate business model; strategies and creation of awareness. The provision of door to door banking marketing awareness, establishment of financial literacy; consumer protection programs 
and Provision of non-interest banking programs.Studies in India reveals that clients were able to utilize microfinance products to increase their income, social welfare and the microfinance is positively associated with increased income and asset buildup. Microfinance interventions are well-recognized world over as an effective tool for poverty alleviation and improving socio-economic status of the rural poor.

Previous study exposed that for MFIs to effectively function and mitigate poverty, visionary, transformational and goal driven leadership style is a prerequiste. A statemanship that will be result oriented and ensure effective public services to these organiztions. The study additional indicated that creativity, innovative, transparent, futuristic leadership qualities and inundating on all the policies and programs is highly required for microfinancial institutions in Nigeria to address the phenomenon of poverty (Ezeanata Walter, \& Parimoo, 2016).

\section{Recommendation}

The study recommended for an establishment of Islamic microfinance and Takful insurance programs to avail the poor and potential customers the opportunity to access interest free loan and business coverage in case of lost. The need for microfinance banks especially those operating in the Northern part of the country to be proactive in product development became imperative. Since the religious precepts of the people in north make them abhor interest on loans and lending schemes.Provision of infrastructural facilities such as good road network, electricity, and security across the towns as well as villages to increase the output of micro entrepreneurs. Special attention should be given to power supply as this constitutes a major cost to microfinance banks in the country. Microfinance policies; programs should further be publicized and advertised via the media so that the poor will be aware of the services of these institutions to access financial awareness to expand their businesses. The provision of capacity building for the staff and customers of these microfinancial institutions to ensure service delivery and Provision of appropriate business model to reduce the poverty level in the northern region of Nigeria.Review of the policies in the areas of licensing and ownership; capital requirementsand recapitalization. These institutions required adequate capital in order to increase accessibility of the funds by the small scale business and the poor respectively.

\section{Conclusion}

Thestudy concluded that the results exposed that MFIs were classified into formal, informal, development and mortgage outlook. Other types explored consist of community banks, public or government owned; private, foreign microfinance and Islamic microfinancial institutions. We have discovered some policies such as Paid-up capital requirements, the permissible and acceptance of several types of deposits including savings, time, and target from individuals, groups and associations. The non-permissible activities are prohibited from engaging into foreign exchange transactions, international commercial papers. International corporate finance; international electronic funds transfer and clearing house activities respectively. The study also discovered lack of access to electricity supply; inadequate supervision and loan defaults. Unsustainable intervention programs; Insufficient cheap funds; Low public awareness and poor regulatory enforcement; poor communication and Lack of banking experience among poor and low-income earners; High operating cost; Low literacy rate among the population; Insufficient donor funding, loan and equity. Limited standardized reporting and performance monitoring system. The informants suggested for efffective regulatory control via financial control, regular supervisor; checks and balances.Capacity building programs for the poor and staff developmentwere recommededappropriate business model; awarenesscampaign among others. The provision of door to door banking marketing awareness, establishment of financial literacy; consumer protection programs and Provision 
of non-interest banking programs were advocated to revamp the ills of MFIs on poverty reduction and empowerment. Practically, the study will encourage policy makers to redifined the policies on MFIs in the quest to mitigate poverty in the Nigeria context.Methodologically, the use of qualitative paradigm on MFIs was applied which explored the perceptions of the interviewees on the strategic policies to empower the poor and small scale businesses and farmers respectively. However, the limitations of this study comprises of the application of nonprobability sampling technique and selection of few states from the nineteen states in northern Nigeria. In order to overcome these limitations future study should apply quantitative design to achieve generalizability; covering all the northern part of the country and a mixed method research is again recommmeded to overcome the apparent weaknesses of this paper.

\section{References}

Acha Ikechukwu, A. (2012). Microfinance banking in Nigeria: Problems and prospects. International Journal of Finance and Accounting, 1(5), 106-111.

Adeyemi, K. S. (2008). Institutional reforms for efficient micro finance operations in Nigeria. Publication of the Central Bank of Nigeria, 26.

Ako, R. M. (2017). The Poverty-Democracy Nexus: Evidence from Nigeria. International Journal of Advanced Studies in Economics and Public Sector Management, 5(1), 2354-4228.

Alkire, S., \& Seth, S. (2015). Multidimensional poverty reduction in India between 1999 and 2006: Where and how?. World Development, 72, 93-108.

Akinwale, A. A. (2010). The menace of inadequate infrastructure in Nigeria. African Journal of Science, Technology, Innovation and Development, 2(3), 207-228.

Anyanwu, C. M. (2004, November). Microfinance institutions in Nigeria: policy, practice and potentials. In G24 Workshop on "Constraints to Growth in Sub Saharan Africa," Pretoria, South Africa.

Bakhtiari, S. (2011). Microfinance and poverty reduction: some international evidence. International Business \& Economics Research Journal (IBER), 5(12).

Creswell, J. W. (1994). Research design: Qualitative and quantitative: London, United Kingdom. Sage publishers.

Ebomuche, N. C., Ihugba, O. A., \& Bankong, B. (2014). The Impact of Nigeria Microfinance Banks on Poverty Reduction: Imo State Experience. International Letters of Social and Humanistic Sciences, (16), 92-113.

Edwin, A. M., Taiwo, J. N., Yewande, O. A., \& Benson, K. N. (2016). The Role of Microfinance Institutions in Financing Small Businesses. The Journal of Internet Banking and Commerce, 21(1).

Ezeanata Walter, C., \& Parimoo, D. (2016). Leadership Development In The Nigerian Micro Finance Banks And Its Effects On The Banks Performances. Leadership, 1(2), 15-24.

Foster, J. E. (1998). Absolute versus relative poverty. The American Economic Review, 88(2), 335-341.

Ikeanyibe, O. M. (2009). Human resource management for sustainable microfinance institutions in Nigeria. Global Journal of Social Sciences, 8(1), 119.

Imai, K. S., Arun, T., \& Annim, S. K. (2010). Microfinance and household poverty reduction:New evidence from India. World Development, 38(12), 1760-1774.

Kamili, S. J. I.(2016) Impact of Microfinance on Self Help Groups in Developing Countries with special reference to India. International Journal of Business and Social Science, 7 (10), 2219-1933.

Kanu, C. (2017). The Problems, Prospects and Social Consequences of Sustainable Rural Business in 
Nigeria. International Journal, 5(1).

Khan, A., \& Cheri, L. (2016). An Examination of Poverty as the Foundation of Crisis in Northern Nigeria. Insight on Africa, 8(1), 59-71.

Liman, N., Hashim, M. K., \& Arshad, D. (2017). A Study on the Types of Microfinance Institutions in Nigeria. MAYFEB Journal of Business and Management, 2.

Ogujiuba, K., Jumare, F., \& Stiegler, N. (2013). Challenges of microfinance access in Nigeria:Implications for entrepreneurship development. Mediterranean Journal of Social Sciences, 4 (6), 2039-2117

Okpara, G. C. (2010). Microfinance banks and poverty alleviation in Nigeria. Journal of Sustainable development in Africa, 12(6), 177-191.

Olomola, A. S. (2002). Social capital, microfinance group performance and poverty implications in Nigeria. Ibadan, Nigeria: Nigerian Institute of Social and Economic Research, 1-25.

Panjaitan-Drioadisuryo, R. D., \& Cloud, K. (1999). Gender, self-employment and microcredit programs An Indonesian case study. The Quarterly Review of Economics and Finance, 39(5), 769-779.

Riessman, C. K. (1993). Narrative analysis (Vol. 30). Sage.Riessman, C. K. (2005). Narrative analysis. Narrative, memory \& everyday life, 1-7.

Sanusi, L. S. (2012). Banking reform and its impact on the Nigerian economy. CebBN Journal of Applied Statistics, 2(2), 115-122.

Saravanan, S., \& Dash, D. P. (2017). Growth and distribution of microfinance in India: A panel data analysis. Theoretical and Applied Economics, 22 (1 (610), Spring), 127-146.

Siwale, J., \& Okoye, N. (2017). Microfinance regulation and social sustainability of microfinance institutions: the case of Nigeria and Zambia. Annals of Public and Cooperative Economics.

Taiwo, J. N., Alege, P. O., \& Olokoyo, F. O. (2016). Microfinancing and micro-enterprises growth in Nigeria. Lagos Journal of Banking, Finance \& Economic, 3(1), 87-119.

Taiwo, J. N., Yewande, O. A., Edwin, A. M., \& Benson, K. N. (2016). The role of microfinance institutions in financing small businesses. Journal of Internet Banking and Commerce, 21(1), 1.

Tansey, O. (2007). Process tracing and elite interviewing: a case for non-probability: Political Science and Politics, 40, (4).

Yahaya, K. A., \& Osemene, O. F. (2011). Effectiveness of microfinance banks in alleviating poverty in Kwara State Nigeria. Global Journal of Management and Business Research, 11(4).

\section{Copyrights}

Copyright for this article is retained by the author(s), with first publication rights granted to the journal. 